\title{
The Electric Supply System of Berlin
}

$\mathrm{I}^{\mathrm{N}}$ a paper read to the Institution of Electrical Engineers on May 13, M. W. Davies gave an account of the electric supply system of Berlin and of recent changes and developments that have taken place in it.

Berlin is a rapidly growing eity. At the time of the Great War, it was still comparatively small, but was surrounded by a number of satellite towns each possessing its own electric supply system. In 1920 these towns were combined to form Greater Berlin, which is to-day more than half the size of Greater London, and has half its population. It covers an area of 300 square miles and has a population of more than four millions. The average density of the population is almost the same as that of London, but in Berlin the greater part of the population lives in flats, with the result that only 28 per cent of the total area is fully developed. The central district is bordered by lakes and woods covering a further 27 per cent. The remaining 45 per cent is mainly undeveloped country and small holdings. As a result of this concentration, the actual density of the population in central Berlin is very high.

In Great Britain a considerable part of the electric energy sold for domestic purposes is used for heating ; but in many parts of the Continent, owing to the extensive use of steam-heating, the development of an electrical heating load is very difficult. In winter, the temperature is often below zero. Most of the flats are equipped with steam central-heating, and so it is not easy to get a satisfactory market for electric cookers and water heaters. Mr. Davies made a special study of the Berlin Power and Light, Co.known in Germany as the 'Bewag'. He describes how the Company in 1924 attempted to solve the dis. tribution problem for this great industrial city by treating it as a single unit. In 1929 and during subsequent years, this method had to be modified in the light of experience.

The bulk of the electrical power in Berlin is supplied from two large central stations, Klingenberg on the east of the city and Kraftwerk West on the west. A large part of the power for the base load is imported over $100 \mathrm{kv}$. lines which bring power from two large stations on the lignite field in central Germany. These stations are relics of the War, and are gradually being extended. The only other station of importance is the one at Charlottenburg, which was reconditioned in 1929. It is fitted with pass-out turbines connected directly to a public steam-heating system. In addition, it has Ruths steam accumulators and so can deliver $73,000 \mathrm{k} . w . h$. per charge at a maximum rate of 50,000 k.v.a.

These steam accumulators are of great value in enabling the system to get over the peak load, which formerly caused some of the lines to be 'tripped' out of the supply. They can be put on to full load in a few seconds and so prevent a stoppage. A 25,000 k.w. steam accumulator is kept constantly on the lines, and furnishes part of the basic load. The average load of the whole system is very high, being $\mathbf{3 6} \cdot 2$ per cent of the maximum possible. The total consumption of electricity in Berlin is about 350 units per head of the population, which is larger than most other Continental cities.

For local government purposes, Berlin is divided into twenty districts, and sixteen of these are now supplied with electricity by the Bewag. The unification was not a sudden achievement, but was the result of careful planning. The movement started with the pooling of generating resources and was afterwards followed by that highly desirable result, the pooling of common tariffs.

\section{The Flax Industry in Great Britain}

\begin{abstract}
$\mathrm{A}^{\mathrm{N}}$
$\mathrm{N}$ interesting account of the history of flax production in Great Britain and the possible line of its development was given by Mr. G. O. Searle at the Annual Conference of the Textile Institute held in London on June 3-5. Though demands are increasing, the production of flax in Great Britain has fallen. In 1864 the total acreage in flax was 320,000 , but in 1930 only a tenth of this, since when it has been even lower and rather variable. With the exception of a few hundred acres in East Anglia, flax-growing remains a peasant industry centred in Northern Ireland. Careful selection and breeding has resulted in the production of varieties yielding nearly fifty per cent more fibre per acre than the older commercial seed.
\end{abstract}

The re-establishment of a flax industry in England depends on changing radically the sequence of processing operations and substituting mechanical methods for manual labour. A flax factory must do more than merely centralise the simple handeraft methods still largely used. Improved methods and new machinery must be developed for the four operations of handling, de-seeding, retting and scutching. Inasmuch as for the last three the flax is required in a thin layer, the expedient of sewing it into mats has been adopted, but this has not as yet been done in the process of harvesting. Such mats greatly simplify the handling of the fibres, and avoid the lifting, untying and re-tying of bundles as at present. The fibres remain in mats during the retting, drying and scutching, a machine for scutch. ing which will take the flax laterally as supplied continuously in the mat, having been developed. With these improvements in processing, the reestablishment of a flax industry in England on a permanent basis is possible.

Various aspects of the question of separating flax fibres from the plant stem were discussed at the Conference by Dr. W. H. Gibson, director of the Linen Industry Research Association. He emphasised the fact that, in the long run, the best results can be efficiently achieved only on the basis of a more profound knowledge of the character of the fibres, and of the tissues in which they are embedded, than 